\title{
Detection of African horse sickness virus antibodies by ELISA in sera collected from unvaccinated horses in Kaduna Metropolis, Nigeria
}

\author{
D.O. Ehizibolo ${ }^{*}$ E.C. Nwokike ${ }^{2}$ Y. Wungak ${ }^{1}$ \\ C.A. Meseko ${ }^{1}$
}

\section{Keywords}

African horse sickness virus antibodies - ELISA - Nigeria.

\begin{abstract}
Summary
African horse sickness (AHS) is endemic in sub-Saharan Africa and is recognized as one of the major life-threatening diseases of equids in some parts of the world. Several sporadic outbreaks of AHS have been reported in Nigeria in the past. Sera collected from 284 horses in seven stables in Kaduna Metropolis, Nigeria, were tested for antibodies against AHS virus (AHSV) using a blocking enzyme-linked immunosorbent assay (ELISA). A high percentage of the sera $(86.6 \%)$ were positive, indicating continual exposure of Nigerian horses to AHSV. Annual vaccination of horses and vector control to minimize incidence in the region is advocated.
\end{abstract}

\section{INTRODUCTION}

African horse sickness (AHS) is endemic in sub-Saharan Africa and is still recognized as one of the major life-threatening diseases of equids in Africa, the Middle East, the Eastern Mediterranean and some parts of Europe (10) because of its high mortality rate (up to $90 \%$ in epidemics), particularly in naïve populations (13). AHS is an acute or subacute insect-borne infectious disease of Equidae (horses, mules, donkeys and zebras) caused by African horse sickness virus (AHSV), a double-stranded RNA virus in the genus orbivirus, belonging to the Reoviridae family $(2,4)$. AHSV is a viscerotropic virus found in the blood, tissue fluids, serous exudates and several internal organs of Equidae (11). It is a non-contagious disease known to be transmitted to horses by midges, in particular by Culicoides imicola, the main field vector found in abundance in Nigeria during the warm rainy seasons (1, 5). The incubation period ranges from 2 to 14 days and the clinical signs appear 5 to 7 days after infection, associated with respiratory and circulatory impairment $(11,13)$.

1. Virology Division, National Veterinary Research Institute, Vom, Nigeria.

2. Equitation Wing, Nigerian Defence Academy, Kaduna, Nigeria.

* Corresponding author

Cell.: +2348035924859

E-mail: kingdavid_e@yahoo.com
AHSV exists as nine immunologically distinct serotypes, all of which have been identified and are considered to be enzootic in sub-Saharan Africa (7). Since the first documented outbreak and subsequent isolation of the virus from a dead horse in Nigeria in 1970 (9), sporadic outbreaks of AHS have occurred in different regions of the country $(3,8,16)$. Furthermore, Lazarus et al. (12) reported in 2010 AHSV in a captive zebra that died in a game reserve in Bauchi, Nigeria. AHSV was detected from tissue samples collected from the dead zebra at postmortem by realtime reverse-transcription polymerase chain reaction (rRT-PCR). Recently (in 2014), outbreaks of AHS have been reported in South Africa and Mozambique resulting in the death of several horses $(15,19)$. Historically, only serotypes 4 and 9 AHS viruses have been found in West Africa. In recent past, other types of AHSV have been reported for the first time in sub-Saharan Africa. AHSV serotype 6 was identified in Ethiopia in 2003 and AHSV serotype 2 was also confirmed in Senegal and Nigeria in 2007 (17). So far, only AHSV serotypes 2 and 9 have been confirmed in Nigeria (3, $8,9)$.

The population of horses in Nigeria has been estimated at over 1.2 million (18) consisting of both a local breed (Arewa), which is popular with traditional institutions, and exotic breeds (particularly Argentine and Sudanese) mostly kept under intensive management by a few elites for racing and polo games. This study shows the presence of antibodies against AHSV in horses in Kaduna, Nigeria. 


\section{MATERIALS AND METHODS}

\section{Study area and stable management}

Kaduna State is located in the Northwestern region of Nigeria, in the Northern Guinea savannah zone. Horses in seven different stables, designated A through $\mathrm{G}$ (Figure 1), belonging to government security institutions $(n=2)$, private organizations $(n=4)$ and a traditional institution $(n=1)$ located in Kaduna Metropolis, Nigeria, were used for the study. These stables were kept under intensive to semi-intensive management and each accommodated 30 to 200 horses. The horses were primarily kept for special ceremonial activities, training, crowd control, race competition and polo games. Routine veterinary care was provided for all the stables except stable G. No preventive vaccination is routinely applied against AHSV in Nigeria.

\section{Sample collection}

Using the principles of convenient sampling, about $50 \%$ of the total number of horses in each stable was selected for blood sampling. A total of 284 horses of all ages, different breeds and both sexes were sampled under proper restraint. Approximately ten milliliters of blood was collected from each horse into properly labeled Vacutainer tubes. The blood samples were allowed to clot and were then centrifuged in the laboratory at $1500 \mathrm{~g}$ for $10 \mathrm{~min}$. Sera were separated into cryovials and stored at $-20^{\circ} \mathrm{C}$ until tested.

\section{Test procedure}

An African horse sickness virus blocking enzyme-linked immunosorbent assay (ELISA) kit (INGENASA, Madrid, Spain) was used for the detection of group-specific antibodies to AHSV in equine (i.e. the test detects all nine serotypes [6]) according to the manufacturer's instruction. Briefly, the antigen was fixed in a solid support (polystyrene plate). After incubation with serum samples, an AHSV specific monoclonal antibody (Mab peroxidase conjugate) was added. If the sample contains specific antibodies to the virus, they will not allow the binding of labeled Mab to the antigen, whereas if the sample does not contain specific antibodies, Mab will bind to the antigen coating the plate. After washing the plate with a multichannel pipetting device suitable for dispensing

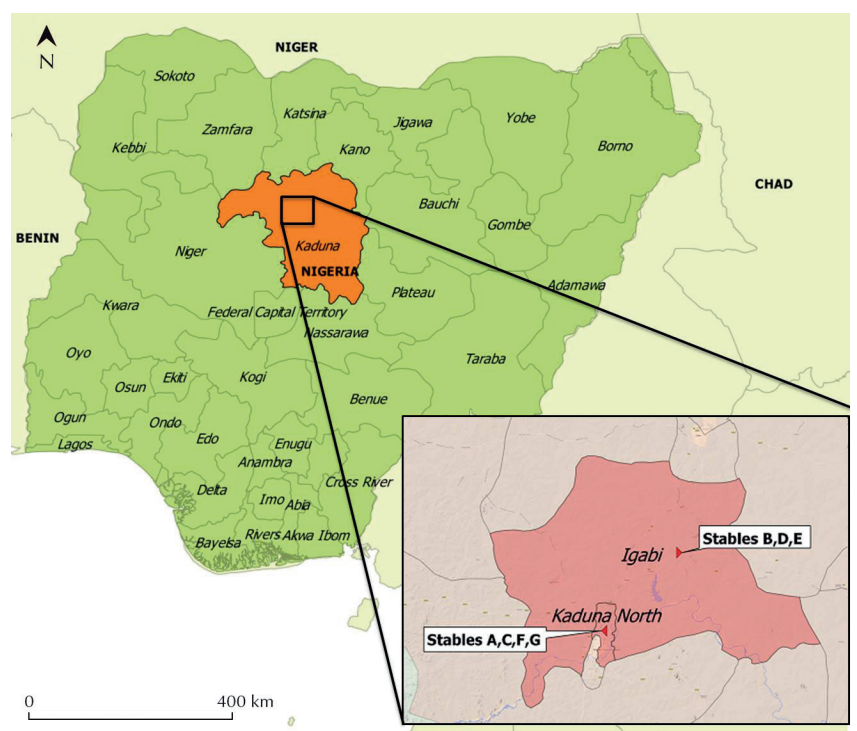

Figure 1: Location of the seven horse stables of the study in Kaduna Metropolis, Nigeria
$300 \mathrm{ml}$ on each well to eliminate all non-fixed materials, presence or absence of labeled Mab can be detected by adding the substrate which, in the presence of peroxidase, will develop a colorimetric reaction. The optical density reading was performed with a spectrophotometer at $405 \mathrm{~nm}$. Samples showing blocking percentages higher than $50 \%$ were considered positive for antibodies to AHSV.

\section{RESULTS}

The stables sampled, breed, sex and age range of the horses are presented in Table I. Results show that overall there was a high prevalence of antibodies in the sera from all the stables included in the study. In total, $246(86.6 \%)$ of the 284 tested horses were positive for antibody to AHSV by ELISA. Stable A had the highest prevalence (100\%), whereas stable E had the lowest (73.3\%). There was a high prevalence of antibodies in the sera collected from the local (Arewa breed) horses $(87.7 \% ; 121 / 138)$, as well as in those collected from exotic (Argentine and Sudanese breeds) horses $(85.6 \% ; 125 / 146)$. The difference between AHSV antibodies detected in local and exotic horses was not statistically significant $\left(\chi^{2}=0.113\right.$; $\left.p>0.05\right)$.

\section{DISCUSSION}

The prevalence of AHSV antibodies detected by ELISA in the horse stables in Kaduna Metropolis, Northwest Nigeria, was estimated at $86.6 \%$. This high prevalence is consistent with previous serological studies in Nigeria $(2,14,16)$, and may be an indication of continual exposure of the horses regardless of age, sex and breed. Our study area (Kaduna) extends from the tropical savannah of Guinea to the savannah of Sudan, with thick vegetation and hot and dry climatic conditions which favor vector propagation and virus transmission. In Nigeria, no preventive vaccination is routinely applied against AHSV, particularly in indigenous and local crossbred horses. There appears to be a form of innate resistance to infection by AHSV as corroborated by Best et al. (3), and Nawathe et al. (14). It could explain the probable absence of reported outbreak of the disease in the region, despite the high prevalence of antibodies. In contrast, newly imported horses, particularly from AHS-free areas, are susceptible to infection and are therefore usually vaccinated before importation. But once established in the country (the animals of exotic breeds examined during the study had been introduced more than ten years ago or were born in the

\section{Table I}

Detection of African horse sickness virus antibodies by ELISA in horse sera from Kaduna Metropolis, Nigeria

\begin{tabular}{lcccccc}
$\begin{array}{l}\text { Stable } \\
\text { (years) }\end{array}$ & $\begin{array}{c}\text { Num. } \\
\text { samples }\end{array}$ & Breed & Male & Female & $\begin{array}{c}\text { Age } \\
\text { range }\end{array}$ & $\begin{array}{c}\text { ELISA } \\
\text { positive } \\
(\%)\end{array}$ \\
\hline A & 17 & Mixed* & 10 & 7 & $4-10$ & $17(100)$ \\
B & 28 & Exotic & 12 & 16 & $2-9$ & $24(85.7)$ \\
C & 22 & Local & 15 & 7 & $6-22$ & $21(95.4)$ \\
D & 93 & Exotic & 22 & 71 & $3-13$ & $80(86.0)$ \\
E & 15 & Exotic & 3 & 12 & $3-11$ & $11(73.3)$ \\
F & 17 & Local & 16 & 1 & $4-15$ & $14(82.4)$ \\
G & 92 & Local & 22 & 70 & $2-17$ & $79(85.9)$ \\
Total & 284 & & & & & $246(86.6)$
\end{tabular}

\footnotetext{
* Ten exotic and seven local breeds
} 
country), they are seldom revaccinated (2) and are therefore vulnerable to AHSV infection.

\section{CONCLUSION}

This report corroborates previous studies and could suggest a potential threat of AHS to the equine industry in Nigeria, and a continual prevalence of the disease. Annual vaccination of imported horses is advocated. Vector control and good stable management practices may assist in minimizing incidence. Suspected outbreaks should be investigated to ascertain the circulating serotypes in the region.

\section{Acknowledgments}

The authors are grateful to the Executive Director of the National Veterinary Research Institute, Vom, for supplying ELISA kit.

\section{REFERENCES}

1. ADEYEFA C.A.O., DIPEOLU O.O., 1993. Studies on Culicoides species (Latreille, Diptera: Ceratopogonidae) of Nigeria. XI. Species caught around horse stables. Insect Sci. Applic., 14: 211-214.

2. ADEYEFA C.A.O., HAMBLIN C., 1995. Continuing prevalence of African horse sickness in Nigeria. Rev. Elev. Méd. Vét. Pays trop., 48: 31-33.

3. BEST J.R., ABEGUNDE A., TAYLOR W.P., 1975. An outbreak of African horse sickness in Nigeria. Vet. Rec., 97: 394.

4. CHALMERS A.W., 1968. African horse sickness. Equine Vet. J., 1: 1-4.

5. DIPEOLU O.O., 1977. Potential vectors of bluetongue in Nigeria. Bull. Anim. Health Prod. Afr., 25: 17-23.

6. HAMBLIN C., GRAHAM S.D., ANDERSON E.C., CROWTHER J.R., 1990. A competitive ELISA for the detection of group-specific antibodies to African horse sickness virus. Epidemiol. Infect., 104: 303-312.

7. HOWELL P.G., 1962. The isolation and identification of further antigenic types of African horse sickness virus. Onderstepoort J. Vet. Res., 29: 139-149.

8. KAZEEM M.M., RUFAI N., OGUNSAN E.A., LOMBIN L.H., ENURAH L.U., OWOLODUN O., 2008. Clinicopathological features associated with the outbreak of African horse sickness in Lagos, Nigeria. J. Equine Vet. Sci., 28: 594-597.

\section{Résumé}

Ehizibolo D.O., Nwokike E.C., Wungak Y., Meseko C.A. Détection par un test Elisa d'inhibition des anticorps dirigés contre le virus de la peste équine africaine chez des chevaux non vaccinés de la métropole de Kaduna, Nigeria

La peste équipe africaine (PEA), endémique dans les pays subsahariens, est considérée dans certaines parties du monde comme l'une des maladies des équidés les plus mortelles. Plusieurs foyers sporadiques de PEA ont été signalés dans le passé au Nigeria. Des anticorps dirigés contre le virus de la PEA ont été recherchés par un test Elisa d'inhibition dans les sérums de 284 chevaux collectés dans sept écuries de la métropole de Kaduna au Nigeria. Un grand pourcentage de sérums (86,6 p. 100) était positif, témoignant d'une exposition permanente des chevaux nigérians au virus de la PEA. La vaccination annuelle des chevaux et la lutte contre les vecteurs du virus sont recommandées pour limiter l'incidence de la maladie dans la région.

Mots-clés : Virus peste équine africaine - Anticorps - Test Elisa - Nigeria.
9. KEMP G.E., HUMBURG J.M., ALHAJI I., 1971. Isolation and identification of African horse sickness in Nigeria. Vet. Rec., 89: 127-128.

10. KIHM U., ACKERMANN M., 1990. Current information on African horse sickness (AHS). Schweiz Arch. Tierheilkd., 132: 205-210. [in German]

11. KONNERUP N.M., GLUCKSTEIN F.P., 1963. Pantropic viral diseases: African horse sickness. In: Equine medicine and surgery. Santa Barbara, CA, USA, American Veterinary Publication, p. 141-147.

12. LAZARUS D.D., ATUMAN S.S., MSHELIA W.P., FASINA F.O., 2010 A report of African horse sickness in a captive Zebra. In: 47th Annu. Congr. Nigerian Veterinary Medical Association, Benue, Nigeria, 4-8 Oct. 2010, p. 71.

13. MERCK MANUAL, 2014. Overview of African horse sickness. www merckmanual/veterinaryprofessionals/generalizedconditions/africanhorse-sickness. Accessed 12 Feb. 2014

14. NAWATHE D.R., SYNGE E., OKOH A.E.J., ABEGUNDE A., 1981 Persistence of African horse sickness in Nigeria. Trop. Anim. Health Prod., 13: 167-168.

15. NEWS POINT AFRICA, 2014. African horse sickness - South Africa: Kwazulu-Natal, Gauteng. www.newspoint.co.za/story/414/5503-africanhorse-sickness-outbreak-horses-banned-moving-and-out. Accessed 3 March 2014

16. OLADOSU L.A., OLAYEYE O.D., BABA S.S., OMILABU S.A., 1993. Isolation and identification of African horse sickness virus during an outbreak in Lagos, Nigeria. Rev. Sci. Tech. Off. Int. Epizoot., 12: 873-877.

17. SABIROVIC M., LOPEZ M., PATEL K., KINGSTON A., HALL S. 2008. African horse sickness: potential risk factors and the likelihood for the introduction of the disease to the United Kingdom. London, UK, Department for Environment Food \& Rural Affairs. http://archive. defra.gov.uk/foodfarm/farmanimal/diseases/monitoring/documents/ahs_ uk081106.pdf. Accessed 12 Feb. 2014

18. WORLD ORGANISATION FOR ANIMAL HEALTH, 2013. Animal population - Country information. Paris, France, OIE. www.oie.int/ wahis_2/public/wahid.php/countryinformation/Animalpopulation. Accessed 7 July 2014

19. WORLD ORGANISATION FOR ANIMAL HEALTH, 2014. African horse sickness - Mozambique. Paris, France, OIE. www.oie.int/wahis2 public/wahid.php/Reviewreport/Review. Accessed 9 May 2014

Accepted 11 February 2015; Online publication March 2015

\section{Resumen}

Ehizibolo D.O., Nwokike E.C., Wungak Y., Meseko C.A. Detección de anticuerpos contra el virus de la peste equina africana mediante ELISA en sueros colectados de caballos no vacunados en Kaduna Metropolis, Nigeria

La peste equina africana (PEA) es endémica en Africa subsahariana y es reconocida como una de las enfermedades que amenazan la vida de los equinos en algunas partes del mundo. En el pasado, se han reportado varios brotes esporádicos de PEA en Nigeria. Sueros colectados de 284 caballos en siete establos en Kaduna metrópolis, Nigeria, fueron examinados para anticuerpos contra el virus de PEA (PEAV), utilizando el ensayo por inmunoabsorción ligado a enzimas (ELISA). Un alto porcentaje de los sueros $(86,6 \%)$ fueron positivos, indicando una exposición continua de los caballos nigerianos a PEAV. Se recomienda una vacunación anual de los caballos y control de vectores para minimizar la incidencia en la región.

Palabras clave: Virus de la peste equina africana - Anticuerpos - ELISA - Nigeria. 
